\title{
RAGE and Alzheimer's Disease: A Progression Factor for Amyloid- $\beta$-Induced Cellular Perturbation?
}

\author{
Shi Du Yan ${ }^{\mathrm{a}}$, Angelika Bierhaus ${ }^{\mathrm{b}}$, Peter P. Nawroth ${ }^{\mathrm{b}}$, and David M. Sternc, ${ }^{*}$ \\ aDepartment of Pathology, College of Physicians \& Surgeons of Columbia University, New York \\ City, NY, USA \\ bDepartment of Medicine I and Clinical Chemistry, University of Heidelberg, Heidelberg, Germany \\ 'Dean/VPHA Office, College of Medicine, University of Cincinnati, Cincinnati, OH, USA
}

\begin{abstract}
Receptor for Advanced Glycation Endproducts (RAGE) is a multiligand member of the immunoglobulin superfamily of cell surface molecules which serves as a receptor for amyloid- $\beta$ peptide $(A \beta)$ on neurons, microglia, astrocytes, and cells of vessel wall. Increased expression of RAGE is observed in regions of the brain affected by Alzheimer's disease (AD), and A $\beta$-RAGE interaction in vitro leads to cell stress with the generation of reactive oxygen species and activation of downstream signaling mechanisms including the MAP kinase pathway. RAGEmediated activation of p38 MAP kinase in neurons causes A $\beta$-induced inhibition of long-term potentiation in slices of entorhinal cortex. Increased expression of RAGE in an A $\beta$-rich environment, using transgenic mouse models, accelerates and accentuates pathologic, biochemical, and behavioral abnormalities compared with mice overexpressing only mutant amyloid- $\beta$ protein precursor. Interception of $A \beta$ interaction with RAGE, by infusion of soluble RAGE, decreases $A \beta$ content and amyloid load, as well as improving learning/memory and synaptic function, in a murine transgenic model of $A \beta$ accumulation. These data suggest that RAGE may be a therapeutic target for AD.
\end{abstract}

\section{Keywords}

Amyloid- $\beta$; peptide receptor; cerebral blood flow; endothelin-1; immunoglobulin superfamily; long-term potentiation; transgenic model

\section{INTRODUCTION}

Recent studies have tied the pathogenesis of neuronal dysfunction in Alzheimer's disease $(\mathrm{AD})$, at least in part, to the presence of toxic oligomers of the amyloid- $\beta$ peptide $(\mathrm{A} \beta)$ in particular regions of the cerebral cortex [1-4]. This association of $A \beta$ with toxicity in the central nervous system (CNS) and a potential causal role in AD is supported by studies in patients with genetic mutations in the amyloid- $\beta$ protein precursor (A $\beta \mathrm{PP}$; which generates increased levels of $A \beta$ ), and studies in genetically manipulated mice overexpressing mutant forms of A $\beta P P$ and presenilins that also result in increased production of A $\beta$ [1-4]. Studies in cell culture and in vivo, in which $\mathrm{A} \beta$ (usually at high concentrations) has been exposed to cellular elements and toxicities recorded, are supportive of this view, though the relevance

(C) 2009-IOS Press and authors. All rights reserved

*Corresponding author: David M. Stern, MD, Dean/VPHA Office, College of Medicine, University of Cincinnati, 231 Albert Sabin Way, PO Box 670555, Cincinnati, OH 45267-0555, USA. Tel.: +1 513558 7334; Fax: +1 513 558 3512; david.stern@uc.edu. 
of this experimental situation to the more complex in vivo milieu is less direct. Although much work has focused on how $A \beta$ is produced, its assembly into oligomers and fibrils, and its deposition in the brain, the mechanisms through which it exerts toxic effects have been more difficult to discern $[1,4,5]$. While the "amyloid hypothesis" posits a direct relationship between $A \beta$ and neuronal toxicity of $A D$, it does not argue against a molecular pathway [2]. It is clear that high levels of $\mathrm{A} \beta$ exert nonspecific toxicity on a range of cell types (in vivo and in vitro), but the mechanism through which pathophysiologically-relevant levels of $A \beta$ perturb cellular functions remains to be clearly mapped out.

One of the most commonly employed mechanisms through which low concentrations of mediators (physiologic or pathologic) exert their effects is by employing cellular binding sites/receptors to concentrate molecules at the cell surface and magnify their effects via signal transduction. This concept led us to propose that potential cellular acceptor sites for $\mathrm{A} \beta$ might be present and could function as pathologic receptors. In contrast to physiologic receptor-ligand interactions, the recognition of toxic $A \beta$ oligomers by a cell surface structure was more likely to represent properties of a "pattern recognition receptor" whereby a particular secondary/tertiary structure provided the molecular determinants for such an interaction rather than the primary structure [6,7]. Thus, a multiligand receptor was likely to be involved. Furthermore, since $A \beta$ is quite varied in its ability to form molecular assemblies, it was more than likely that several cell surface molecules might be involved, and that these could vary from cell-to-cell. Although one might suggest that such receptors were "scavengers," functioning to dispose toxic material in the environment $[8,9]$, since the interaction between $A \beta$ and the receptor was fortuitous, it was also possible to extend to a wider range of receptors.

The focus of this review is the Receptor for Advanced Glycation Endproducts or RAGE, a member of immunoglobulin superfamily of cell surface molecules that functions as a cell surface receptor for $A \beta[10-12]$. We have hypothesized that RAGE has an integral role in the pathologic properties of $A \beta$ early in the disease process when low levels of toxic $A \beta$ oligomers are exerting their effects as true mediators. Later in the course of disease, when higher concentrations of $\mathrm{A} \beta$ are present and extensive amyloid deposits are observed, multiple other mechanisms including nonspecific toxicity are likely to assume increasing importance in the ultimate death of neurons.

\section{A primer on RAGE: AGEs and RAGE}

RAGE was discovered as part of an effort to identify cellular interaction sites for advanced glycoxidation endproducts (AGEs) [13,14]. AGEs accumulate over time in a variety of tissues and circumstances and are associated with changes in tissue/cell properties and organ dysfunction [15-17]. They form as the result of nonenzymatic glycoxidation [15,17]. Although situations with high levels of reducing sugars, especially in the intracellular environment, speed their formation, oxidant stress is just as important and enzymatic mechanisms brought to bear in inflammation, such as the action of myeloperoxidase, also result in the generation of AGEs [15-17]. Such products of nonenzymatic glycoxidation are also found in AD brain potentially due to the delayed turnover of proteins and the presence of a pro-oxidant environment [18-21]. When high levels of glucose are exposed to proteins for extended periods in vitro, multiple glycoxidation products form, only some of which are relevant to pathobiology in vivo. Nonetheless, certain species are produced in the incubator, which do mimic AGEs found in vivo. Glucose-modified albumin, formed by the prolonged incubation of high levels of glucose with albumin, was used to detect tissue-associated binding proteins in lung extracts. The result of our biochemical analysis of lung tissue was the identification of RAGE [14]. Using a similar set of binding assays, but substituting A $\beta$ for AGEs, we found the RAGE also interacted with amyloid peptide [12]. 
RAGE is a member of the immunoglobulin super-family of cell surface molecules $[10,13]$. Its extracellular domain is composed of three immunoglobulin-like regions, one $\mathrm{N}$-terminal "V"-type domain and two "C"-type domains. There is one transmembrane spanning domain and a short, highly charged cytosolic tail. On SDS-PAGE, RAGE is a single chain species with a migration corresponding to a molecular weight of about 50-55 kDa. Although there is only one RAGE gene in humans, located in proximity to the major histocompatibility complex, there are several alternatively spliced forms that arise from the full-length RAGE transcript $[22,23]$. At least one of these encodes a portion of the molecule corresponding to the extracellular domain and may have a role in regulating access of ligands to RAGE under physiologic/pathologic conditions (see below). Soluble forms of RAGE (i.e., devoid of the transmembrane spanning and cytosolic domains) are termed sRAGE and one particular form produced by alternative splicing is called endogenous secretory RAGE (esRAGE) [24]. The extracellular domain of RAGE is most similar to other members of the immunoglobulin superfamily, such as muc18 and ALCAM [10,11]. Ligand binding properties of the molecule have been predominately localized to the V-type domain present towards the Nterminus of the extracellular portion of the receptor. Recent studies suggest that the Vdomain is closely associated with $\mathrm{C} 1$, but not the $\mathrm{C} 2$, domain, though the crystal structure of the receptor has not been solved as of yet. What is particularly striking about RAGE is its repertoire of ligands. The receptor not only binds AGEs and $A \beta$ but interacts with multiple crossed $\beta$-sheet fibrils, as well as the family of S100/calgranulins, $\beta_{2}$-integrins and high mobility group box 1 protein (HMGB1) [10, 22,25-28].

In the case of AGEs, receptor recognition requires a post-translational modification of the ligand. Thus, although native albumin does not bind RAGE, AGE-modified albumin does bind to RAGE. In the case of amyloid A, although amyloid A in its monomeric state does not bind RAGE, the fibrillar form is a ligand for the receptor [12,29]. Such observations have led to the contention that RAGE is a "pattern recognition receptor," rather than a receptor recognizing the primary structure of ligands (as mentioned in the Introduction, see above). Furthermore, although the precise structural determinants mediating ligand binding to the receptor are not known, it has been theorized that properties associated with $\beta$-sheets may be involved. In this regard, the macromolecular ligands of RAGE appear to crosscompete in studies with RAGE extracellular domain and isolated V-domain. This suggests that the same and/or overlapping ligand binding sites exist in the receptor's binding pocket. We hypothesize that this is a very flexible binding pocket able to accommodate large structures, even fibrils, or structures which are quite different, such as HMGB1. In a recent report, Sturchler and colleagues [30] have indicated that oligomers of A $\beta$ bind to the RAGE $\mathrm{V}$-domain, whereas aggregates are more closely associated with the $\mathrm{C}$-domain. Thus, under certain circumstances it is possible that several domains of the receptor are involved in ligand recognition [31].

The transmembrane spanning and cytosolic domains of RAGE are quite unremarkable. In fact, initial extensive analysis of the cytosolic tail has not turned up compelling insights into proximal events mediating its coupling to signal transduction mechanisms. One report has shown that the MAP kinase family member Erk binds to the RAGE cytosolic tail [32], though the generality and relevance of this mechanism, in view of the broad triggering of signaling events that occurs after ligand engagement of RAGE, is not clear. Considering the prominent connection between RAGE-mediated cellular activation and changes in cell shape/migration, it is likely that the receptor will be coupled to down-stream mechanisms involved in changes in cell shape and motility. Furthermore, since activation of RAGE is also closely tied to generation of reactive oxygen species, at least in part from an NADPH oxidase-like mechanism [21,33,34], it is possible that formin-like proteins are involved in downstream receptor signaling [35,36]. Two observations with respect to intracellular signaling and RAGE are quite compelling: 1) the cytosolic tail is essential for the receptor to 
signal [37]; and 2) oxidant sensitive mechanisms contribute importantly to signal transduction mechanisms initiated by RAGE-ligand interaction [28,34]. In terms of the first observation, when the cytosolic tail of RAGE is deleted (i.e., what remains is a molecule comprised of the extracellular and transmembrane spanning domains), the mutant species has properties of a dominant-negative (DN-RAGE) [37]. Thus, when DN-RAGE is introduced into cells, although it is capable of binding RAGE ligands, RAGE-mediated cellular activation does not occur. Furthermore, even if that cell also expresses wild-type (wt) RAGE, the presence of DN-RAGE blocks signaling from the native receptor also. This suggests, perhaps, that a particular clustering of cytosolic tails of RAGE must occur in order for the receptor to signal. The presence of DN-RAGE may interfere with this.

\section{Linkage of RAGE and its ligands to pathologic conditions}

Links between RAGE and pathobiology are easily suggested when the nature of the receptor's ligands are considered. Multiple examples readily come to mind: AGEs form in an oxidant environment, typical of the setting of inflammation and renal failure [16, 17]. S100 proteins are released at sites of inflammation from polymorphonuclear leukocytes and other effector cells [38,39]. HMGB1 is known for inciting an injurious host response following release from necrotic tissue [38-40]. Macromolecular assemblies of $A \beta$ (and other amyloid-associated peptides/proteins) are associated with degenerative processes, such as AD [41-43]. Furthermore, in certain circumstances, several RAGE ligands are present at the site of lesions; S100 proteins and AGEs are both localized to atherosclerotic lesions in diabetic animals [44,45]; and, AGEs and A $\beta$ assemblies both co-exist in AD brain [12]. Upregulation of RAGE at sites of ligand accumulation facilitates sustained ligand-receptor interaction eventuating in long-term cellular stimulation [10,11,22,28]. It is important to emphasize that in each of these situations, RAGE-ligand interaction appears to have the ability propagate an injurious host response incited by the underlying disease process (AD, diabetic complications, inflammation, etc.), but RAGE does not, per se, cause the basic disease process.

\section{RAGE and amyloid- $\beta$ peptide}

The relevance of RAGE to AD was suggested by increased levels of the receptor in brains of patients with AD compared with nondemented controls [12,46], as well as the receptor binding data mentioned above (RAGE-A $\beta$ interaction). Although when the structure of RAGE is solved, it may be quite rational that $A \beta$ binds to the receptor, it was certainly an unexpected finding experimentally. It is difficult to know exactly which species of $A \beta$ binds to RAGE, though it is becoming increasing evident that it may be a soluble oligomer. However, it is interesting that binding of $A \beta$ to RAGE occurs with fresh preparations of $A \beta_{1-40}$, likely to be largely monomers/oligomers, as well as with aged preparations of $A \beta_{1-42}$ specially made to enrich for oligomers and fibrillar material. Further-more, when $A \beta$ preparations are incubated with RAGE-bearing cells, evidence of cell stress, as manifested by activation of NF- $\kappa B$ and generation of oxidant stress is observed [12]. The latter are consistent with the receptor's ability to mediate "toxic" effects of A $\beta$ on cells consistent with what might be predicted for oligomeric amyloid peptide.

Although binding of $A \beta$ to RAGE in vitro was of interest, the important point was to assess whether such an interaction might occur under more physiologic conditions, and if there were functional consequences. In this regard, mice infused with radioiodinated $A \beta_{1-40}$ demonstrated transport across the blood-brain barrier reflecting capillary uptake [47]. Based on HPLC (high pressure liquid chromatography) and immunostaining, it appeared that transported $A \beta$ was, at least in part, intact, i.e., it was not completely degraded. Such transport of $A \beta$ appeared to depend on the expression of RAGE, as it was blocked by antiRAGE IgG and sRAGE. In addition, such transport was virtually undetectable in 
homozygous RAGE null mice. Consequences of RAGE-dependent uptake of A $\beta$ were probed by analyzing expression of tumor necrosis factor-a (TNFa). Within $30 \mathrm{~min}$ of infusing $A \beta$, increased TNFa transcripts and antigen were evident within the brain parenchyma. Blocking RAGE prevented, in parallel, transport of $A \beta$ and induction of TNFa. Similar observations were made with respect to induction of interleukin- 6 and heme oxygenase type 1 , though the time course was slower than with TNFa.

These observations raised the possibility that RAGE might be a physiologic binding site for $\mathrm{A} \beta$ on the luminal surface of the blood-brain barrier, and that this might be a first step in the transport of amyloid peptide into the brain parenchymal space. If substantial amounts of $A \beta$ entered the brain by this mechanism (either initially or via recirculation over time), then one might expect that preventing access of $A \beta$ to RAGE in the peripheral circulation would decrease the amount of total $A \beta$ in the brain parenchyma. One way to test this was to take advantage of the properties of sRAGE, the extracellular domain of the receptor. Soluble RAGE is a protein of molecular weight $35-40 \mathrm{kDa}$ (depending on carbohydrate content) which binds ligands of the receptor, but does not enter the CNS (as long as the blood-brain barrier is intact). Thus, administration of sRAGE to the peritoneal cavity or intravenously results in sequestration of RAGE ligands outside of the CNS due to binding to sRAGE. Administration of sRAGE for 3 months to mice bearing a transgene for mutant A $\beta P P$ (which results in enhanced production of $\mathrm{A} \beta$ and its subsequent deposition in the brain) [48] decreased the total $\mathrm{A} \beta$ content of the brain and prevented additional brain parenchymal accumulation of $A \beta_{1-42}$ (Fig. 1a,b). Immunohistologic analysis of murine brains for plaquelike lesions revealed a striking decrease in the brains of transgenic mice treated with sRAGE, versus control groups (including those receiving vehicle alone) (Fig. 1c). These data suggest a link between RAGE and circulation/recirculation of $A \beta$ in murine transgenic models. Furthermore, they suggest the existence of a complex equilibrium between $A \beta$ in the brain (behind the blood-brain barrier) and that circulating in the peripheral circulation [47].

From previous studies in cell culture, we knew that engagement of endothelial RAGE resulted in changes in cellular properties. Since focal changes in cerebral blood flow are characteristic of $\mathrm{AD}$, and are also observed in murine models, we sought to determine if $\mathrm{A} \beta$ RAGE interaction was associated with a change in cerebral blood flow, and what mechanisms might underlie such a change. Infusion of $A \beta_{1-40}$ at nanomolar levels into the peripheral circulation was associated with a fall in cerebral blood flow (Fig. 2A,B). Such diminished cerebral blood flow was prevented by administration of anti-RAGE IgG or sRAGE (Fig. 2B), and was not observed to a significant extent in RAGE null mice. These data indicated that $A \beta$ interaction with RAGE on the vessel wall resulted in diminished cerebral blood flow [47].

The time course of this fall in blood flow was interesting in that it was not immediate, but occurred over a $40 \mathrm{~min}$ period after the infusion of $\mathrm{A} \beta$ [47]. There was no change for the first $30 \mathrm{~min}$, and the fall in blood flow occurred over the subsequent 20-40 min (Fig. 2A). This time interval suggested the possible involvement of a biosynthetic/post-translation processing mechanism. This led us to probe if A $\beta$-RAGE interaction at the level of the vasculature might result in the production of a vasoconstrictor mediator such as endothelin-1. In fact, increased levels of immunoreactive endothelin-1 were detected in cerebral vasculature, and endothelin-1A receptor blockers prevented $\mathrm{A} \beta$-induced suppression of cerebral blood flow [47]. In tissue culture, $A \beta$ applied to murine brain endothelial cells resulted in increased expression of preproendothelin-1 mRNA in a RAGEdependent manner [47]. These data pointed to the significance, in physiologic terms, of $A \beta$ interaction with RAGE on the surface of the cerebral circulation. 
The experiments described above were performed under acute conditions, whereas AD and the consequences of amyloid deposition occur over years [49-51]. Thus, we sought a situation in which vascular consequences of exposure to high levels of $A \beta$ were established over months. Our question was whether preventing access of $A \beta$ to vascular RAGE under these conditions might have an effect on properties of the vessel wall [52]. For this purpose, we utilized a different transgenic murine model of AD-type pathology [53]. Mice were aged to 9 months and vessels were stained for immunoreactive endothelin-1 and cerebral blood flow was determined. Cerebral vasculature from the transgenic mice did show increased levels of endothelin-1 associated with the vessels, and cerebral blood flow was decreased, compared with age- and strain-matched nontransgenic controls [47]. Infusion of sRAGE or anti-RAGE IgG into these transgenic animals resulted in an increase in cerebral blood flow (Fig. 3). Thus, even when subjected to an amyloid-rich environment for months, resulting in decreased cerebral blood flow, an intervention preventing the interaction of RAGE with A $\beta$ had a stimulatory effect on cerebral blood flow. These data point to a reversible component of decreased blood flow associated with amyloid vascular pathology, and suggest that RAGE may be a significant player in these settings.

\section{Studies of RAGE in genetically manipulated mice overexpressing mutant A $\beta P P$}

Within the CNS, RAGE is present on neurons and microglia, as well as in the vasculature [12]. In the setting of AD, neuronal RAGE is clearly increased in the A $\beta$-rich environment [12]. This is not unexpected, since RAGE ligands are known to increase expression of the receptor. Although the mechanism in the case of $A \beta$ has not been assessed directly, one possible path-way is through A $\beta$-RAGE-mediated activation of NF- $\mathrm{\kappa B}$ sites in the RAGE promoter $[10,11]$. In view of increased expression of neuronal RAGE in $A D$, we developed a transgenic model with targeted overexpression of RAGE in neurons [54] in an A $\beta$-rich environment (the latter provided by a transgene for mutant A $\beta$ PP driven the PDGF B-chain promoter) [48]. Increased expression of RAGE was also driven by the PDGF B-chain promoter. The double transgenic animals (Tg RAGE/mutant A $\beta P P$ ) overexpressed neuronal RAGE and mutant A $\beta P P$ resulting in deposition of $A \beta$ [54].

By 3-4 months of age, evidence of increased cellular stress was evident in brains of $\mathrm{Tg}$ $\mathrm{RAGE} /$ mutant A $\beta \mathrm{PP}$ mice as demonstrated by appearance of a prominent gel shift band compared with single transgenics (Tg RAGE, Tg mutant A $\beta P P$ ) and strain/age-matched controls (nontransgenics) in electrophoretic mobility shift assays with NF- $\mathrm{\kappa B}$ consensus probe and nuclear extracts from cerebral cortex [54]. Overexpression of RAGE in the A $\beta$ rich environment (Tg RAGE/mutant A $\beta P P$ ) resulted in strong binding activity for the NF$\kappa \mathrm{B}$ probe, compared with single transgenics (Fig. 4A). In addition, transgenics in which wild-type RAGE was replaced with DN-RAGE showed strongly diminished NF- $\kappa \mathrm{B}$ activation (Fig. 4b). DN-RAGE is a form of RAGE from which the cytosolic tail has been deleted (the extracellular and transmembrane domains are intact). Although DN-RAGE is competent to bind ligands, it does not engage signaling pathways and actually functions as a dominant-negative; once introduced to a cell with wild-type RAGE, receptor-mediated cell signaling from RAGE is blocked.

These data with regard to early NF- $\mathrm{BB}$ activation in the cortex of Tg RAGE/mutant A $\beta P P$ mice were the first clue to evidence of multiple abnormalities at the level of behavioral, neuropathologic, and biochemical changes. Studies in the radial arm water maze reflect hippocampal function at the level of spatial learning and memory $[55,56]$. At 3-4 months of age, Tg RAGE/mutant A $\beta P P$ mice (double transgenics) displayed impaired ability to learn the task (acquisition phase of the trials) compared with other groups (non-transgenics and single transgenics, Tg mutant A $\beta$ PP and Tg RAGE) (Fig. 5A). By 5-6 months, spatial learning/memory was impaired in both $\mathrm{Tg} \mathrm{A} \beta \mathrm{PP}$ and double transgenics, though more severely in the Tg RAGE/mutant A $\beta$ PP (Fig. 5B). These data indicated that increased 
expression of RAGE, due to the presence of the RAGE transgene with expression targeted to neurons (within the CNS), accelerated neuronal dysfunction in an A $\beta$-rich environment (provided by the mutant A $\beta P P$ transgene). This led to the question as to what mechanisms might underlie this change in neuronal function. For this purpose, studies of synaptic transmission were performed under long term potentiation (LTP) and basal conditions. Consistent with previous work [48], we observed differences in basal synaptic transmission in animals expressing the mutant $\mathrm{A} \beta \mathrm{PP}$ transgene compared with nontransgenics.

Unexpected was a suppression in LTP which was observed in double transgenics (Tg RAGE/mutant A $\beta P P$ ), but not in other groups of animals [54]. These data were consistent with RAGE-mediated impairment of synaptic plasticity (see below for further studies on the role of RAGE in A $\beta$-mediated perturbation of LTP).

Experiments were also performed using neuropathologic technique to understand implications of enhanced expression of RAGE in an A $\beta$-rich environment. Our first studies assessed the density of cholinergic fibers using a histologic assay for acetylcholinesterase (AChE) activity. The relevance of this approach is supported by the decreased density of cholinergic fibers and synapses seen in AD [57,58]. By 3-4 months of age, the effects of the RAGE transgene were evident in double transgenics; there was a decrease in area occupied by AchE-positive neurites in the subiculum compared with other groups. These changes were enhanced over time, and by 14-18 months of age, Tg RAGE/mutant A $\beta p p$ mice showed even more striking decreased density of AChE-positive neurites.

Further biochemical studies supported the concept that synaptic plasticity was altered when increased levels of neuronal RAGE were introduced into an A $\beta$-rich environment. Studies were performed at the level of phosphorylation of CREB and action of mitogen-activated proteinases as well as calcium/calmodulin-dependent protein (CAM) kinase II. Extracts of the hippocampus were analyzed by immunoblotting. Levels of phospho-CREB were increased in 3-4 month-old double transgenics, compared with groups. In terms of MAP kinases, phosphorylation of $\mathrm{p} 38$ was observed in Tg RAGE/mutant A $\beta P P$ mice, though not in other groups (3-4 months), and increased phosphorylation of Erk1/2 was observed in the double transgenics (there was no change in phosphorylation of JNK with respect to the different transgenics. Levels of phosphorylated CAMK II were also selectively increased in double transgenics, compared with other groups, though this did not occur until 14-18 months ago. Thus, multiple markers associated with synaptic plasticity were altered in mice with increased levels of $A \beta$ and neuronal RAGE [54].

These studies suggest a role for RAGE in the pathogenesis of A $\beta$-induced neuronal dysfunction associated with $\mathrm{AD}$ at several levels; the blood-brain barrier and neurons. More recent studies in which RAGE has been overexpressed in cells of mononuclear phagocyte origin (including microglia) have demonstrated enhanced neuroinflammation with consequences for neuronal function. In view of the increased expression of RAGE in multiple cellular elements in AD brain, it is possible that interception of RAGE-ligand interaction might be a therapeutic approach in this devastating dementia.

\section{Mechanisms of A $\beta$-mediated perturbation of synaptic plasticity: role of RAGE}

Changes in synaptic strength over longer periods of time, as modeled by LTP, contribute to learning and memory in multiple regions of the brain $[59,60]$. A $\beta$ is known to inhibit LTP [61], and administration of naturally secreted human $A \beta$ oligomers at nanomolar concentrations blocks development of LTP in the hippocampus $[4,62,63]$. Although at higher levels of $A \beta$ (micromolar range), this might be due to $A \beta$ engagement of multiple different receptors, we sought to determine if RAGE might be involved in this nanomolar effect of $A \beta$ oligomers [64]. Using entorhinal slices from brains of wild-type mice and animals with genetically manipulated RAGE expression, we studied the effect of oligomeric 
$\mathrm{A} \beta_{1-42}(200 \mathrm{nM})$ on LTP. High frequency stimulation of the slices according to a previously described protocol reproducibly resulted in the development of LTP [65]. Addition of oligomeric $A \beta_{1-42}(200 \mathrm{nM})$ prevented the development of LTP in wt mice (Fig. 6). In the presence of anti-RAGE IgG, A $\beta$-induced loss of LTP could be prevented in entorhinal slices from wt mice (Fig. 6). In contrast, using homozygous RAGE null mice, the same preparations of $A \beta$ were ineffective in preventing the development of LTP. To further assess the underlying mechanism at the level of the receptor, we employed mice expressing a dominant negative form of RAGE also expressed in cortical neurons (driven by the PDGF B-chain promoter as above). The latter, transgenic DN-RAGE mice also displayed protection from A $\beta$-induced inhibition of LTP [64]. Thus, binding of A $\beta$ to RAGE must be followed by receptor-mediated activation of the target cell (which does not occur in cells bearing DN-RAGE) in order to A $\beta$ to block the development of LTP.

To probe the specificity of the electrophysiologic events underlying A $\beta$-RAGE-mediated perturbation of LTP, we extended our studies to long-term depression (LTD) of synaptic transmission. Using a protocol to induce LTD in entorhinal slices, application of A $\beta$ had no effect, consistent with a previous report [63]. Similarly, in RAGE null mice, induction of LTD was also normal. Thus, the effect of A $\beta$ on LTP, mediated by RAGE, is selective and does not reflect broad inhibition of electrical/neuronal activity in the cell.

Since RAGE-mediated signal transduction appeared to be necessary for A $\beta$-induced inhibition of LTP, we examined downstream pathways activated by stimulation of the receptor. The MAP kinases were a prime candidate as both JNK and p38 have been implicated in the effect of A $\beta$ on LTP in a previous study [66]. Furthermore, we have previously found MAP kinases to be involved in RAGE-mediated cellular activation in other contexts [67] and in double transgenic mice overexpressing RAGE and mutant human A $\beta P P$ [54]. Using selective inhibitors of JNK and p38 MAP kinase, we found that selective inhibition of $\mathrm{p} 38$, but not JNK, blocked the effect of A $\beta$ on LTP. Consistent with these data, cell culture experiments with neurons and $A \beta_{1-42}$, a nontoxic concentration $(200 \mathrm{nM})$, demonstrated activation/phosphorylation of p38 MAP kinase that was blocked by inhibition of RAGE with specific antibodies [64].

RAGE is also present on microglia and astrocytes, as well as neurons and cells of the bloodbrain barrier (endothelial and smooth muscle cells) [12]. Experiments are underway to determine the contribution of A $\beta$-RAGE-mediated cellular activation to the biology of $\mathrm{AD}$.

\section{CONCLUSION}

Our studies suggest the merit of a receptor-driven hypothesis for mediating cellular perturbation by $A \beta$ at early stages of the disease process when concentrations of toxic $A \beta$ oligomers are low. There are likely to be multiple receptors for $A \beta$, and several have been implicated over the years [68]. We propose that RAGE is one of these. The relevance of RAGE to the pathogenesis of neural dysfunction is supported by increased expression in AD brain, studies in animals with genetically manipulated mice, and the presence of RAGE on multiple cell types contributing to ultimate neuronal dysfunction in AD, including cells of the blood brain barrier, microglia and astrocytes, in addition to neurons. Studies in mice are strongly suggestive of an effect in man, but we must await results of clinical trials with RAGE blockers in AD.

\section{Acknowledgments}

The work of Dr. Yan was supported by a grant from the USPHS (P01 AG17490). Dr. Stern is a consultant for and/ or receives lecture fees from AstraZeneca, High Point Pharmaceuticals LLC, NovoNordisk, and TransTech Pharma, Inc. 


\section{REFERENCES}

1. Cerpa W, Dinamarca MC, Inestrosa NC. Structure-function implications in Alzheimer's disease: effect of Abeta oligomers at central synapses. Curr Alzheimer Res. 2008; 5:233-243. [PubMed: 18537540]

2. Hardy J. Has the amyloid cascade hypothesis for Alzheimer's disease been proved? Curr Alzheimer Res. 2006; 3:71-73. [PubMed: 16472206]

3. Viola KL, Velasco PT, Klein WL. Why Alzheimer's is a disease of memory: the attack on synapses by A beta oligomers (ADDLs). J Nutr Health Aging. 2008; 12:51S-57S. [PubMed: 18165846]

4. Walsh DM, Selkoe DJ. A beta oligomers - a decade of discovery. J Neurochem. 2007; 101:11721184. [PubMed: 17286590]

5. Roses AD. On the discovery of the genetic association of Apolipoprotein E genotypes and common late-onset Alzheimer disease. J Alzheimers Dis. 2006; 9:361-366. [PubMed: 16914873]

6. Lee MS, Kim YJ. Pattern-recognition receptor signaling initiated from extracellular, membrane, and cytoplasmic space. Mol Cells. 2007; 23:1-10. [PubMed: 17464205]

7. Rezaei N. Therapeutic targeting of pattern-recognition receptors. Int Immunopharmacol. 2006; 6:863-869. [PubMed: 16644471]

8. Adachi H, Tsujimoto M. Endothelial scavenger receptors. Prog Lipid Res. 2006; 45:379-404. [PubMed: 16712941]

9. Moore KJ, Freeman MW. Scavenger receptors in atherosclerosis: beyond lipid uptake. Arterioscler Thromb Vasc Biol. 2006; 26:1702-1711. [PubMed: 16728653]

10. Bierhaus A, Humpert PM, Morcos M, Wendt T, Chavakis T, Arnold B, Stern DM, Nawroth PP. Understanding RAGE, the receptor for advanced glycation end products. J Mol Med. 2005; 83:876-886. [PubMed: 16133426]

11. Schmidt AM, Yan SD, Yan SF, Stern DM. The multi-ligand receptor RAGE as a progression factor amplifying immune and inflammatory responses. J Clin Invest. 2001; 108:949-955. [PubMed: 11581294]

12. Yan SD, Chen X, Fu J, Chen M, Zhu H, Roher A, Slattery T, Zhao L, Nagashima M, Morser J, Migheli A, Nawroth P, Stern D, Schmidt AM. RAGE and amyloid-beta peptide neurotoxicity in Alzheimer's disease. Nature. 1996; 382:685-691. [PubMed: 8751438]

13. Neeper M, Schmidt AM, Brett J, Yan SD, Wang F, Pan YC, Elliston K, Stern D, Shaw A. Cloning and expression of a cell surface receptor for advanced glycosylation end products of proteins. $\mathrm{J}$ Biol Chem. 1992; 267:14998-15004. [PubMed: 1378843]

14. Schmidt AM, Vianna M, Gerlach M, Brett J, Ryan J, Kao J, Esposito C, Hegarty H, Hurley W, Clauss M, et al. Isolation and characterization of two binding proteins for advanced glycosylation end products from bovine lung which are present on the endothelial cell surface. J Biol Chem. 1992; 267:14987-14997. [PubMed: 1321822]

15. Bierhaus A, Hofmann MA, Ziegler R, Nawroth PP. AGEs and their interaction with AGEreceptors in vascular disease and diabetes mellitus. I. The AGE concept. Cardiovasc Res. 1998; 37:586-600. [PubMed: 9659442]

16. Brownlee M. The pathobiology of diabetic complications: a unifying mechanism. Diabetes. 2005; 54:1615-1625. [PubMed: 15919781]

17. Thomas MC, Baynes JW, Thorpe SR, Cooper ME. The role of AGEs and AGE inhibitors in diabetic cardiovascular disease. Curr Drug Targets. 2005; 6:453-474. [PubMed: 16026265]

18. Smith MA, Taneda S, Richey PL, Miyata S, Yan SD, Stern D, Sayre LM, Monnier VM, Perry G. Advanced Maillard reaction end products are associated with Alzheimer disease pathology. Proc Natl Acad Sci USA. 1994; 91:5710-5714. [PubMed: 8202552]

19. Yen SH, Liu WK, Hall FL, Yan SD, Stern D, Dickson DW. Alzheimer neurofibrillary lesions: molecular nature and potential roles of different components. Neurobiol Aging. 1995; 16:381-387. [PubMed: 7566347]

20. Yan SD, Fu J, Soto C, Chen X, Zhu H, Al-Mohanna F, Collison K, Zhu A, Stern E, Saido T, Tohyama M, Ogawa S, Roher A, Stern D. An intracellular protein that binds amyloid-beta peptide and mediates neurotoxicity in Alzheimer's disease. Nature. 1997; 389:689-695. [PubMed: 9338779] 
21. Yan SD, Yan SF, Chen X, Fu J, Chen M, Kuppusamy P, Smith MA, Perry G, Godman GC, Nawroth P, et al. Non-enzymatically glycated tau in Alzheimer's disease induces neuronal oxidant stress resulting in cytokine gene expression and release of amyloid beta-peptide. Nat Med. 1995; 1:693-699. [PubMed: 7585153]

22. Bierhaus A, Stern DM, Nawroth PP. RAGE in inflammation: a new therapeutic target? Curr Opin Investig Drugs. 2006; 7:985-991.

23. Schlueter C, Hauke S, Flohr AM, Rogalla P, Bullerdiek J. Tissue-specific expression patterns of the RAGE receptor and its soluble forms-a result of regulated alternative splicing? Biochim Biophys Acta. 2003; 1630:1-6. [PubMed: 14580673]

24. Takeuchi A, Yamamoto Y, Tsuneyama K, Cheng C, Yonekura H, Watanabe T, Shimizu K, Tomita K, Yamamoto H, Tsuchiya H. Endogenous secretory receptor for advanced glycation endproducts as a novel prognostic marker in chondrosarcoma. Cancer. 2007; 109:2532-2540. [PubMed: 17497647]

25. Chavakis T, Bierhaus A, Al-Fakhri N, Schneider D, Witte S, Linn T, Nagashima M, Morser J, Arnold B, Preissner KT, Nawroth PP. The pattern recognition receptor (RAGE) is a counterreceptor for leukocyte integrins: a novel pathway for inflammatory cell recruitment. J Exp Med. 2003; 198:1507-1515. [PubMed: 14623906]

26. Muhammad S, Barakat W, Stoyanov S, Murikinati S, Yang H, Tracey KJ, Bendszus M, Rossetti G, Nawroth PP, Bierhaus A, Schwaninger M. The HMGB1 receptor RAGE mediates ischemic brain damage. J Neurosci. 2008; 28:12023-12031. [PubMed: 19005067]

27. Orlova VV, Choi EY, Xie C, Chavakis E, Bierhaus A, Ihanus E, Ballantyne CM, Gahmberg CG, Bianchi ME, Nawroth PP, Chavakis T. A novel pathway of HMGB1-mediated inflammatory cell recruitment that requires Mac-1-integrin. EMBO J. 2007; 26:1129-1139. [PubMed: 17268551]

28. Schmidt AM, Hori O, Brett J, Yan SD, Wautier JL, Stern D. Cellular receptors for advanced glycation end products. Implications for induction of oxidant stress and cellular dysfunction in the pathogenesis of vascular lesions. Arterioscler Thromb. 1994; 14:1521-1528. [PubMed: 7918300]

29. Yan SD, Zhu H, Zhu A, Golabek A, Du H, Roher A, Yu J, Soto C, Schmidt AM, Stern D, Kindy M. Receptor-dependent cell stress and amyloid accumulation in systemic amyloidosis. Nat Med. 2000; 6:643-651. [PubMed: 10835680]

30. Sturchler E, Galichet A, Weibel M, Leclerc E, Heizmann CW. Site-specific blockade of RAGE-Vd prevents amyloid-beta oligomer neurotoxicity. J Neurosci. 2008; 28:5149-5158. [PubMed: 18480271]

31. Dattilo BM, Fritz G, Leclerc E, Kooi CW, Heizmann CW, Chazin WJ. The extracellular region of the receptor for advanced glycation end products is composed of two independent structural units. Biochemistry. 2007; 46:6957-6970. [PubMed: 17508727]

32. Ishihara K, Tsutsumi K, Kawane S, Nakajima M, Kasaoka T. The receptor for advanced glycation end-products (RAGE) directly binds to ERK by a D-domain-like docking site. FEBS Lett. 2003; 550:107-113. [PubMed: 12935895]

33. Wautier MP, Chappey O, Corda S, Stern DM, Schmidt AM, Wautier JL. Activation of NADPH oxidase by AGE links oxidant stress to altered gene expression via RAGE. Am J Physiol Endocrinol Metab. 2001; 280:E685-E694. [PubMed: 11287350]

34. Yan SD, Schmidt AM, Anderson GM, Zhang J, Brett J, Zou YS, Pinsky D, Stern D. Enhanced cellular oxidant stress by the interaction of advanced glycation end products with their receptors/ binding proteins. J Biol Chem. 1994; 269:9889-9897. [PubMed: 8144582]

35. Le Clainche C, Carlier MF. Regulation of actin assembly associated with protrusion and adhesion in cell migration. Physiol Rev. 2008; 88:489-513. [PubMed: 18391171]

36. Ridley AJ. Rho GTPases and actin dynamics in membrane protrusions and vesicle trafficking. Trends Cell Biol. 2006; 16:522-529. [PubMed: 16949823]

37. Hofmann MA, Drury S, Fu C, Qu W, Taguchi A, Lu Y, Avila C, Kambham N, Bierhaus A, Nawroth P, Neurath MF, Slattery T, Beach D, McClary J, Nagashima M, Morser J, Stern D, Schmidt AM. RAGE mediates a novel proinflammatory axis: a central cell surface receptor for S100/calgranulin polypeptides. Cell. 1999; 97:889-901. [PubMed: 10399917]

38. Klune JR, Dhupar R, Cardinal J, Billiar TR, Tsung A. HMGB1: endogenous danger signaling. Mol Med. 2008; 14:476-484. [PubMed: 18431461] 
39. Voll RE, Urbonaviciute V, Herrmann M, Kalden JR. High mobility group box 1 in the pathogenesis of inflammatory and autoimmune diseases. Isr Med Assoc J. 2008; 10:26-28. [PubMed: 18300566]

40. Rauvala H, Rouhiainen A. RAGE as a receptor of HMGB1 (Amphoterin): roles in health and disease. Curr Mol Med. 2007; 7:725-734. [PubMed: 18331230]

41. Cappai R, Barnham KJ. Delineating the mechanism of Alzheimer's disease A beta peptide neurotoxicity. Neurochem Res. 2008; 33:526-532. [PubMed: 17762917]

42. Harrison RS, Sharpe PC, Singh Y, Fairlie DP. Amyloid peptides and proteins in review. Rev Physiol Biochem Pharmacol. 2007; 159:1-77. [PubMed: 17846922]

43. Irie K, Murakami K, Masuda Y, Morimoto A, Ohigashi H, Hara H, Ohashi R, Takegoshi K, Fukuda H, Nagao M, Shimizu T, Shirasawa T. The toxic conformation of the 42-residue amyloid beta peptide and its relevance to oxidative stress in Alzheimer's disease. Mini Rev Med Chem. 2007; 7:1001-1008. [PubMed: 17979802]

44. Park L, Raman KG, Lee KJ, Lu Y, Ferran LJ Jr, Chow WS, Stern D, Schmidt AM. Suppression of accelerated diabetic atherosclerosis by the soluble receptor for advanced glycation endproducts. Nat Med. 1998; 4:1025-1031. [PubMed: 9734395]

45. Soro-Paavonen A, Watson AM, Li J, Paavonen K, Koitka A, Calkin AC, Barit D, Coughlan MT, Drew BG, Lancaster GI, Thomas M, Forbes JM, Nawroth PP, Bierhaus A, Cooper ME, JandeleitDahm KA. Receptor for advanced glycation end products (RAGE) deficiency attenuates the development of atherosclerosis in diabetes. Diabetes. 2008; 57:2461-2469. [PubMed: 18511846]

46. Lue LF, Walker DG, Brachova L, Beach TG, Rogers J, Schmidt AM, Stern DM, Yan SD. Involvement of microglial receptor for advanced glycation endproducts (RAGE) in Alzheimer's disease: identification of a cellular activation mechanism. Exp Neurol. 2001; 171:29-45. [PubMed: 11520119]

47. Deane R, Du Yan S, Submamaryan RK, LaRue B, Jovanovic S, Hogg E, Welch D, Manness L, Lin C, Yu J, Zhu H, Ghiso J, Frangione B, Stern A, Schmidt AM, Armstrong DL, Arnold B, Liliensiek B, Nawroth P, Hofman F, Kindy M, Stern D, Zlokovic B. RAGE mediates amyloid-beta peptide transport across the blood-brain barrier and accumulation in brain. Nat Med. 2003; 9:907-913. [PubMed: 12808450]

48. Hsia AY, Masliah E, McConlogue L, Yu GQ, Tatsuno G, Hu K, Kholodenko D, Malenka RC, Nicoll RA, Mucke L. Plaque-independent disruption of neural circuits in Alzheimer's disease mouse models. Proc Natl Acad Sci U S A. 1999; 96:3228-3233. [PubMed: 10077666]

49. Giri R, Selvaraj S, Miller CA, Hofman F, Yan SD, Stern D, Zlokovic BV, Kalra VK. Effect of endothelial cell polarity on beta-amyloid-induced migration of monocytes across normal and AD endothelium. Am J Physiol Cell Physiol. 2002; 283:C895-C904. [PubMed: 12176746]

50. Giri R, Shen Y, Stins M, Du Yan S, Schmidt AM, Stern D, Kim KS, Zlokovic B, Kalra VK. betaamyloid-induced migration of monocytes across human brain endothelial cells involves RAGE and PECAM-1. Am J Physiol Cell Physiol. 2000; 279:C1772-C1781. [PubMed: 11078691]

51. Donahue JE, Flaherty SL, Johanson CE, Duncan JA 3rd, Silverberg GD, Miller MC, Tavares R, Yang W, Wu Q, Sabo E, Hovanesian V, Stopa EG. RAGE, LRP-1, and amyloid-beta protein in Alzheimer's disease. Acta Neuropathol. 2006; 112:405-415. [PubMed: 16865397]

52. Mackic JB, Stins M, McComb JG, Calero M, Ghiso J, Kim KS, Yan SD, Stern D, Schmidt AM, Frangione B, Zlokovic BV. Human blood-brain barrier receptors for Alzheimer's amyloid-beta 140. Asymmetrical binding, endocytosis, and transcytosis at the apical side of brain microvascular endothelial cell monolayer. J Clin Invest. 1998; 102:734-743. [PubMed: 9710442]

53. Hsiao K, Chapman P, Nilsen S, Eckman C, Harigaya Y, Younkin S, Yang F, Cole G. Correlative memory deficits, Abeta elevation, and amyloid plaques in transgenic mice. Science. 1996; 274:99102. [PubMed: 8810256]

54. Arancio O, Zhang HP, Chen X, Lin C, Trinchese F, Puzzo D, Liu S, Hegde A, Yan SF, Stern A, Luddy JS, Lue LF, Walker DG, Roher A, Buttini M, Mucke L, Li W, Schmidt AM, Kindy M, Hyslop PA, Stern DM, Du Yan SS. RAGE potentiates Abeta-induced perturbation of neuronal function in transgenic mice. EMBO J. 2004; 23:4096-4105. [PubMed: 15457210]

55. Diamond DM, Park CR, Heman KL, Rose GM. Exposing rats to a predator impairs spatial working memory in the radial arm water maze. Hippocampus. 1999; 9:542-552. [PubMed: 10560925] 
56. Petrone A, Battaglia F, Wang C, Dusa A, Su J, Zagzag D, Bianchi R, Casaccia-Bonnefil P, Arancio O, Sap J. Receptor protein tyrosine phosphatase alpha is essential for hippocampal neuronal migration and long-term potentiation. EMBO J. 2003; 22:4121-4131. [PubMed: 12912911]

57. Geula C. Abnormalities of neural circuitry in Alzheimer's disease: hippocampus and cortical cholinergic innervation. Neurology. 1998; 51:S18-S29. discussion S65-S17. [PubMed: 9674759]

58. Masliah E, Terry RD, DeTeresa RM, Hansen LA. Immunohistochemical quantification of the synapse-related protein synaptophysin in Alzheimer disease. Neurosci Lett. 1989; 103:234-239. [PubMed: 2505201]

59. Harvey CD, Svoboda K. Locally dynamic synaptic learning rules in pyramidal neuron dendrites. Nature. 2007; 450:1195-1200. [PubMed: 18097401]

60. Malenka RC, Bear MF. LTP and LTD: an embarrassment of riches. Neuron. 2004; 44:5-21. [PubMed: 15450156]

61. Selkoe DJ. Alzheimer's disease is a synaptic failure. Science. 2002; 298:789-791. [PubMed: 12399581]

62. Walsh DM, Klyubin I, Fadeeva JV, Cullen WK, Anwyl R, Wolfe MS, Rowan MJ, Selkoe DJ. Naturally secreted oligomers of amyloid beta protein potently inhibit hippocampal long-term potentiation in vivo. Nature. 2002; 416:535-539. [PubMed: 11932745]

63. Wang HW, Pasternak JF, Kuo H, Ristic H, Lambert MP, Chromy B, Viola KL, Klein WL, Stine WB, Krafft GA, Trommer BL. Soluble oligomers of beta amyloid (1-42) inhibit long-term potentiation but not long-term depression in rat dentate gyrus. Brain Res. 2002; 924:133-140. [PubMed: 11750898]

64. Origlia N, Righi M, Capsoni S, Cattaneo A, Fang F, Stern DM, Chen JX, Schmidt AM, Arancio O, Yan SD, Domenici L. Receptor for advanced glycation end product-dependent activation of p38 mitogen-activated protein kinase contributes to amyloid-beta-mediated cortical synaptic dysfunction. J Neurosci. 2008; 28:3521-3530. [PubMed: 18367618]

65. Kourrich S, Chapman CA. NMDA receptor-dependent long-term synaptic depression in the entorhinal cortex in vitro. J Neurophysiol. 2003; 89:2112-2119. [PubMed: 12612002]

66. Wang Q, Walsh DM, Rowan MJ, Selkoe DJ, Anwyl R. Block of long-term potentiation by naturally secreted and synthetic amyloid beta-peptide in hippocampal slices is mediated via activation of the kinases c-Jun N-terminal kinase, cyclin-dependent kinase 5, and p38 mitogenactivated protein kinase as well as metabotropic glutamate receptor type 5. J Neurosci. 2004; 24:3370-3378. [PubMed: 15056716]

67. Sakaguchi T, Yan SF, Yan SD, Belov D, Rong LL, Sousa M, Andrassy M, Marso SP, Duda S, Arnold B, Liliensiek B, Nawroth PP, Stern DM, Schmidt AM, Naka Y. Central role of RAGEdependent neointimal expansion in arterial restenosis. J Clin Invest. 2003; 111:959-972. [PubMed: 12671045]

68. Yan SD, Roher A, Chaney M, Zlokovic B, Schmidt AM, Stern D. Cellular cofactors potentiating induction of stress and cytotoxicity by amyloid beta-peptide. Biochim Biophys Acta. 2000; 1502:145-157. [PubMed: 10899440] 
a

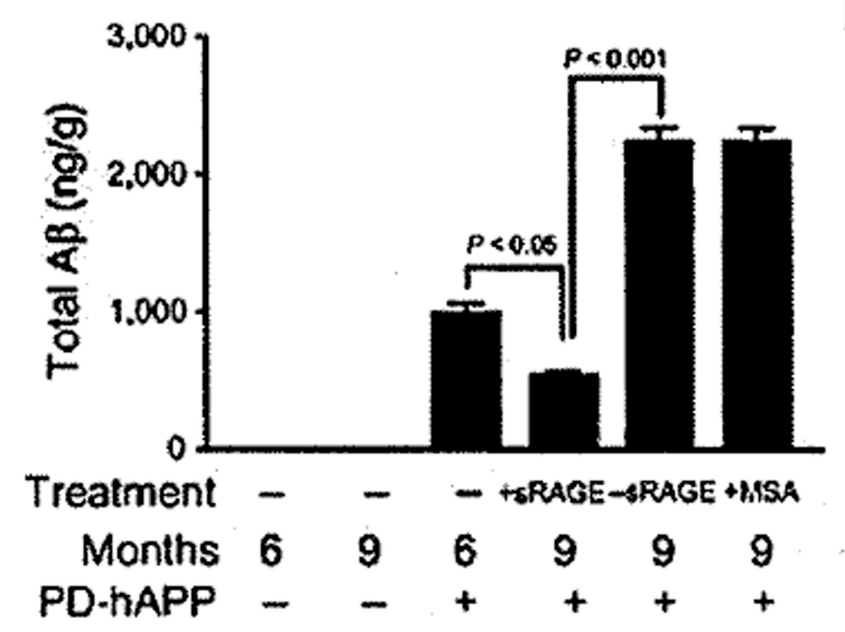

b

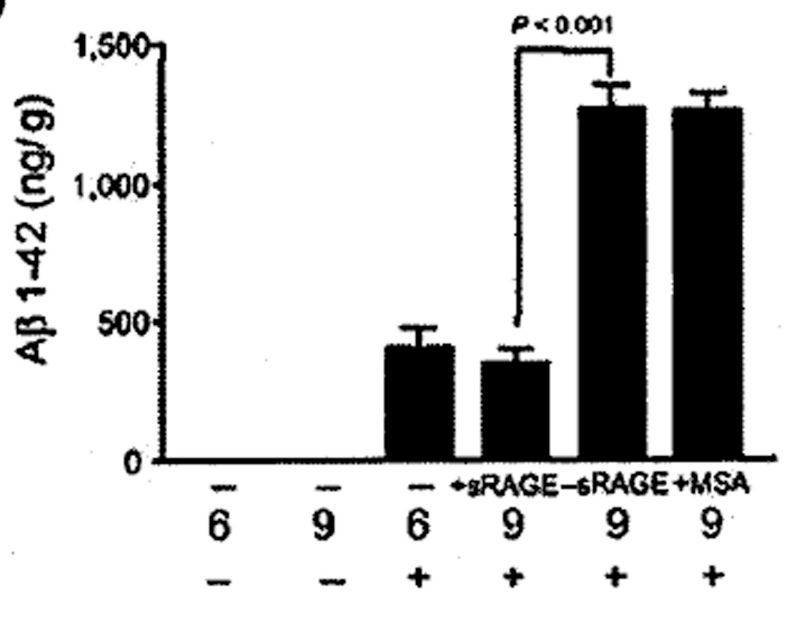

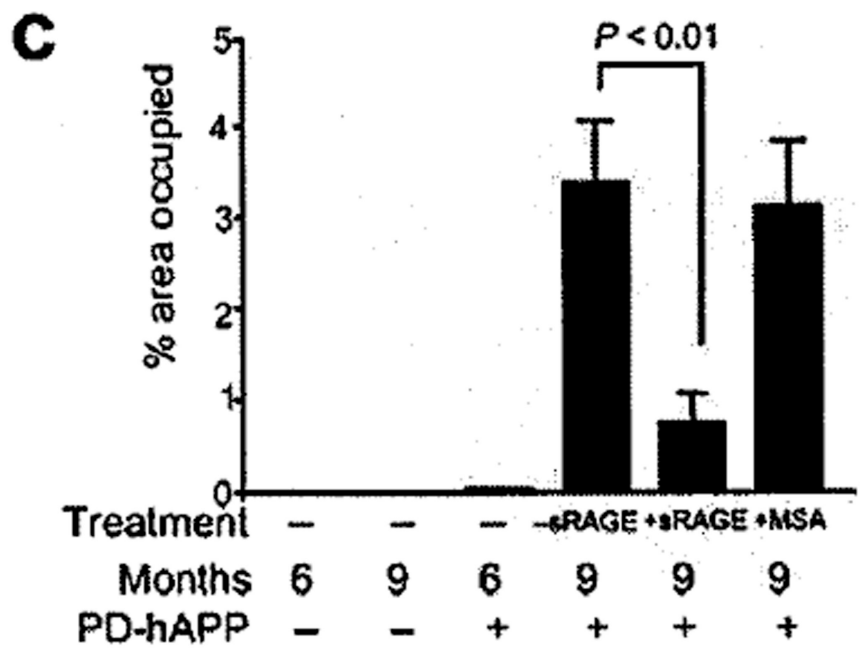

Fig. 1.

Administration of sRAGE to mice bearing a mutant human A $\beta P P$ transgene (Tg PD-hAPP mice) reduces cerebral amyloidosis. Total $A \beta$ (panel a) and $A \beta_{1-42}$ (panel b) were determined by ELISA in nontransgenic (negative for the transgene) or transgenic PD-hAPP mice (+ for the transgene) who were administered sRAGE (or vehicle) from the ages of 6-9 months, as indicated. In panel c, image analysis of amyloid load from the experiments in panels a-b is shown. Adapted from Deane et al. [47]. 
a b

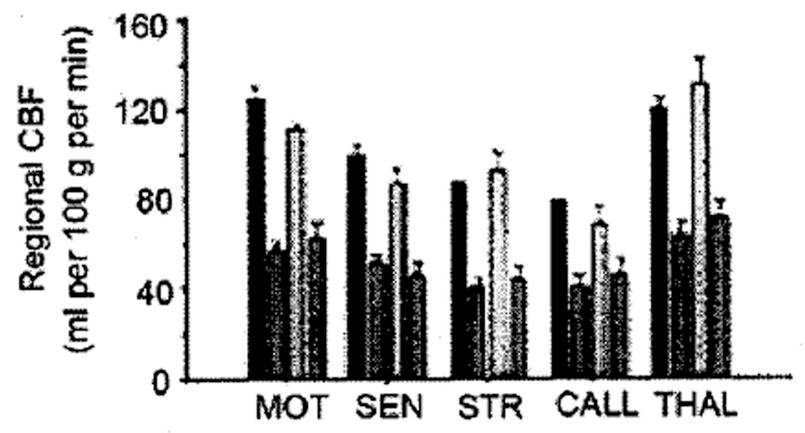

Fig. 2.

Cerebral blood flow, $\mathrm{A} \beta$, and RAGE. a) Cerebral blood flow (CBF) and systemic blood pressure (BP) are shown after infusion of human $A \beta_{1-40}$ at the indicated time, b) Regional CBF after administration of vehicle (red), $A \beta_{1-40}$ (orange), $A \beta_{1-40}+$ anti-RAGE IgG (yellow); $A \beta_{1-40}+$ nonimmune IgG (green) was determined in the motor cortex (MOT), sensory cortex (SEN), striatum (STR), callosum (CALL) and thalamus (THAL). Adapted from Deane et al. [47]. (Colours are visible in the electronic version of the article at www.iospress.nl) 


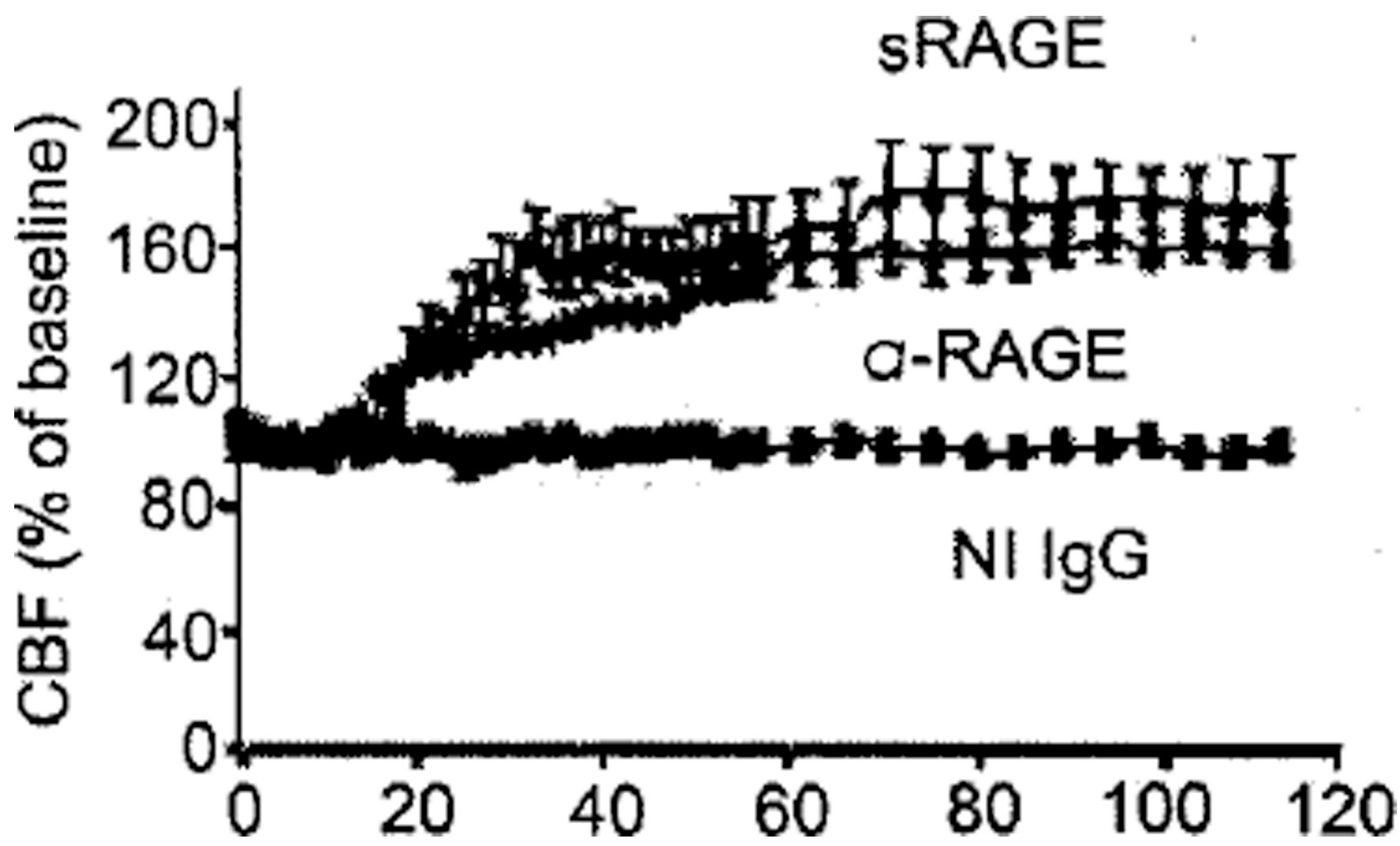

Fig. 3.

Increased cerebral blood flow in 9 month old Tg2576 mice treated anti-RAGE IgG ( $a$ RAGE), sRAGE but not nonimmune (NI) IgG. Adapted from Deane et al. [47]. 

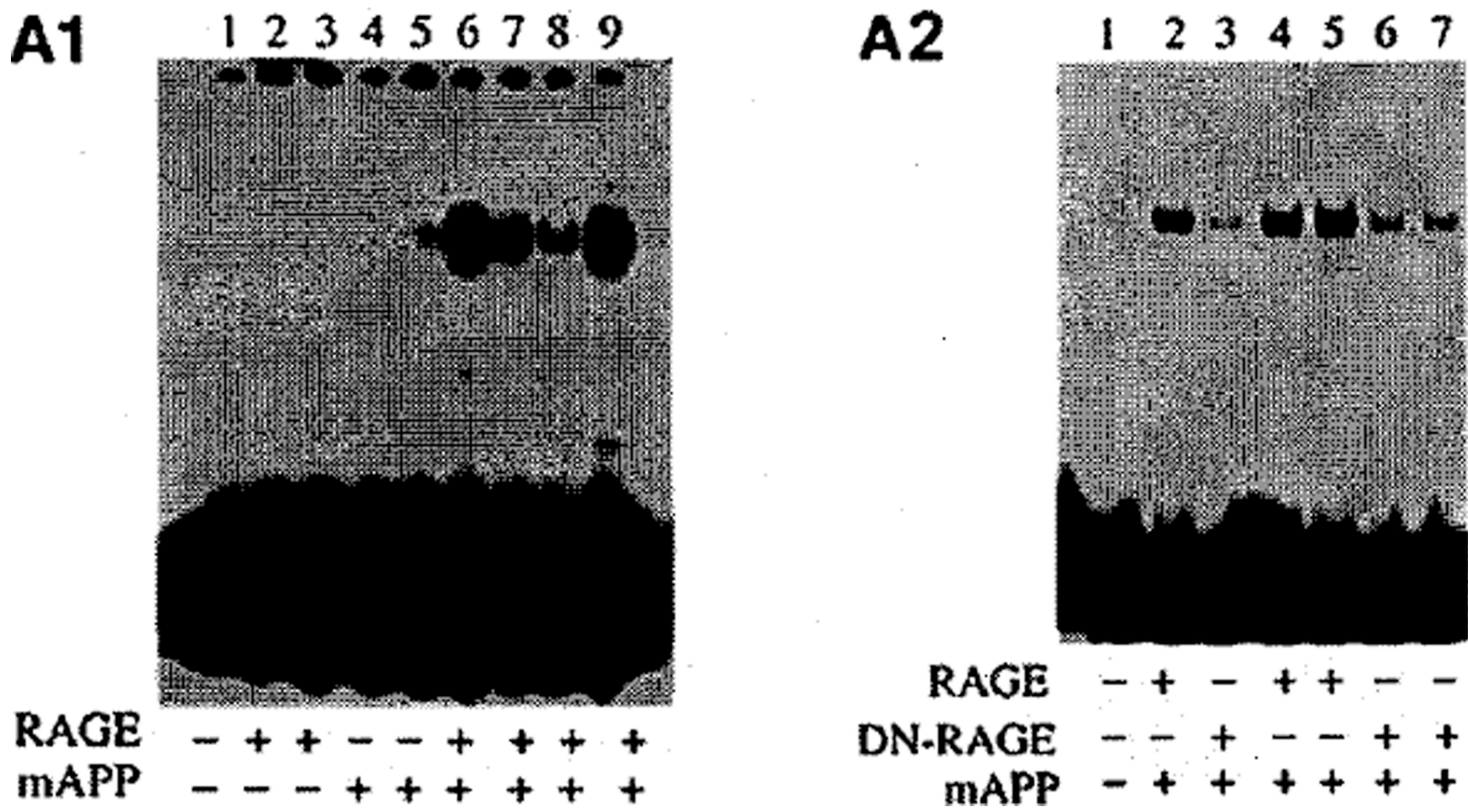

Fig. 4.

Nuclear extracts from cerebral cortex of 3-4-month old double transgenic mice bearing a transgene driving overexpression of neuronal RAGE and a transgene expressing mutant human amyloid precursor protein were studied by electrophoretic mobility shift assay using a consensus NF- $\kappa$ B probe. A1) RAGE indicates the presence $(+)$ or absence (-) of the RAGE transgene. mAPP indicates the presence $(+)$ or absence $(-)$ of the mutant amyloid precursor protein transgene. A2) The same experiment as in panel A1 was conducted, but certain double transgenics had the wild-type RAGE transgene replaced by a transgene encoding dominant negative (DN) RAGE. The presence (+) or absence (-) of the DNRAGE transgene is indicated. Adapted from Arancio et al. [54] 

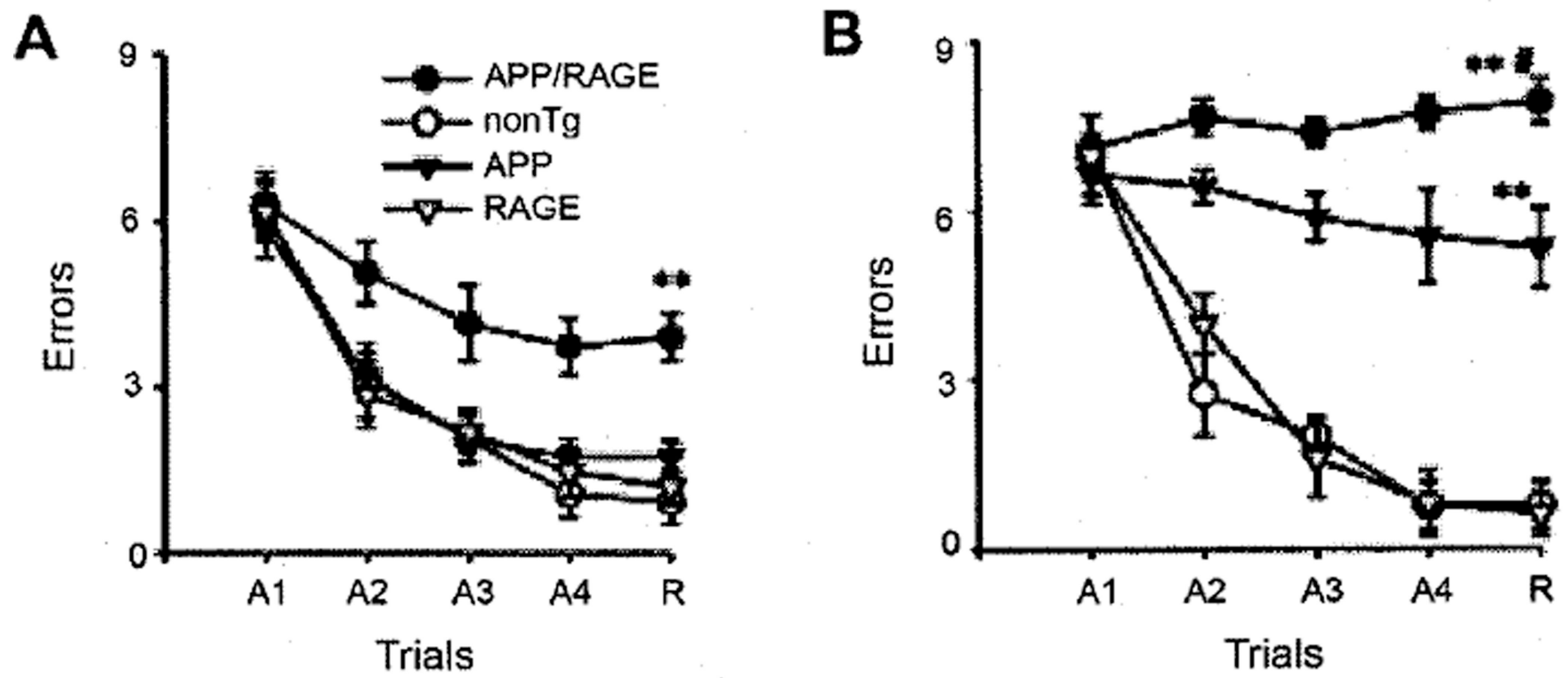

Fig. 5.

Analysis of spatial learning and memory in double transgenic mice (Tg RAGE/mAPP) using the radial arm water maze at 3-4 (A) and 5-6 (B) months of age. Symbols denote: RAGE, mice expressing the RAGE transgene only; APP, mice expressing the mutant A $\beta P P$ transgene only; nonTg, nontransgenic age- and strain-matched littermates; and APP/RAGE, double transgenic mice expressing the mutant $\mathrm{A} \beta \mathrm{PP}$ and RAGE transgenes. Adapted from Arancio et al. [54]. 


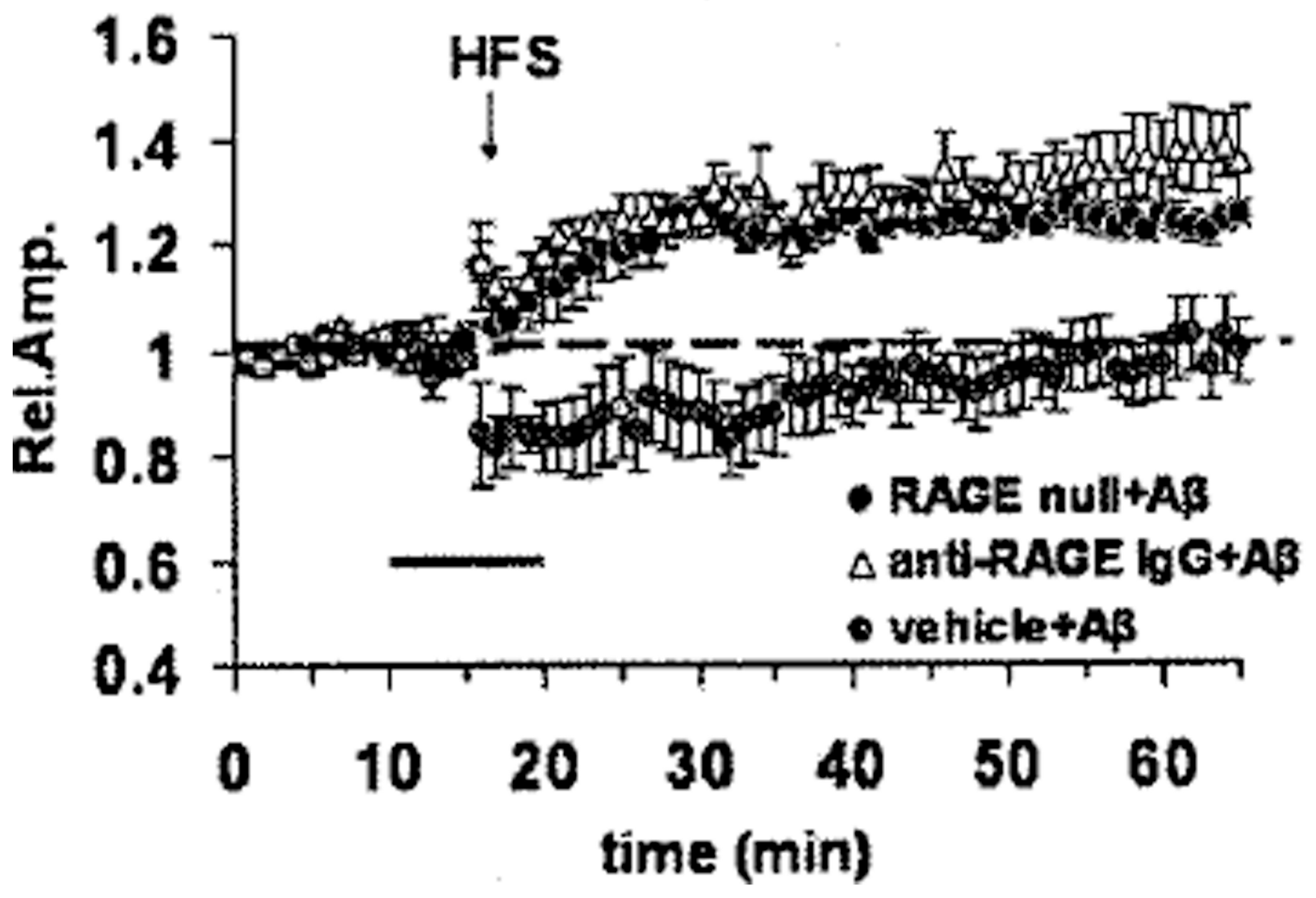

Fig. 6.

Effect of RAGE on $A \beta_{1-42}(200 \mathrm{nM})$-induced inhibition of LTP in slices of entorhinal cortex. Exposure to A $\beta$ (dark bar) did not prevent development of LTP in samples derived from homozygous RAGE null mice or in slices from wild-type mice preincubated with blocking antibody to RAGE. Vehicle-treated slices from wild-type mice exposed to A $\beta$ are shown in grey. HFS = high frequency stimulation protocol used to induce LTP in cortical slices. Adapted from Origlia [64]. 